\title{
Performance Modeling and Parametric Analysis of a Double Glazed Solar Oven
}

\author{
Abdul Waheed Badar, Syed Ali Zaryab, Zain Ul Abedin, and Muhammad Yasin Khan
}

\begin{abstract}
This paper investigates the thermal performance of a unique box type solar oven whose five sides are exposed to ambient and provisions are also provided to install the reflectors to enhance the intensity of incident solar radiation on the oven. Experiments were performed where temperatures attained inside the box cavity are recorded on different days and times of the day corresponding to various intensities of available solar radiation. A steady sate heat transfer numerical model of the solar oven without reflectors is also developed based on six individual thermal resistance networks which account for the heat losses through each flat-side of the oven box and a good agreement with the experimental data is achieved. A parametric study based on numerical calculations and experiments is then carried out to study the effects of various parameters on oven's thermal performance, e.g. number of glazings, distance between glazings and box, type of absorber coating, etc. Higher box temperature is attained using double glazing than single glazing. As compared to black paint, selective surface coating results in significantly higher oven temperatures (up to $40^{\circ} \mathrm{C}$ ). Plate spacing of $20-30 \mathrm{~mm}$ is found to be optimum distance between oven box and glass covers.
\end{abstract}

Index Terms-Solar oven, oven box temperature, reflectors, overall heat transfer coefficient.

\section{INTRODUCTION}

A solar oven uses solar energy to heat, cook and pasteurize food materials. Solar cookers are easily available in the market, most of them are relatively in expensive and low tech, while others are expensive, advanced and as powerful as a stove. Studies have been done on the thermal performance and parameters that affect the performance of simple box type solar ovens which takes solar radiations from the top surface [1], [2]. Solar cookers having varying cover thickness have also been tested [3]. Research has also been done on double glazed solar oven which takes radiation only from the top surface [4], [5]. A simple box type solar oven has been created in Egypt and its performance was studied [6]. For thermal performance testing of solar cooker mathematical models have been presented by Garg et al. [7], and Vaishya $e t$ al. [8]. Theoretical model have also been presented for double glazed solar oven receiving solar radiation from two sides [9], [10]. Yadav and Tiwari [11] carried out a transient analytical study of box type solar cooker with one surface exposed to solar radiation.

Manuscript received September 7, 2014; revised July 12, 2015.

Abdul Waheed Badar is with National University of Sciences and Technology, Pakistan (e-mail: awbdr@yahoo.com).

Syed Ali Zaryab is with the Business Technology Service Department of HBL, Sindh, Pakistan.

Zain Ul Abedin was with National University of Sciences and Technology, Pakistan.

Muhammad Yasin Khan is with the Renewable Energy Promoters at Chichawatni, Pakistan.
In this work, a unique five sided double glazed solar oven with a black painted box as the cooking cavity is investigated. Fig. 1 shows the pictorial view of the oven with and without reflectors. The design of this solar cooker is unique as it can intercept beam, diffuse and ground reflected solar radiation from five sides with the aid of upper and lower reflectors which augment the incident radiation intensity. Compared to concentrated type of cookers, major advantage of this cooker is that during cooking the person doesn't shade the cooker and also there is no possibility to come in direct contact with the concentrated intense radiation.

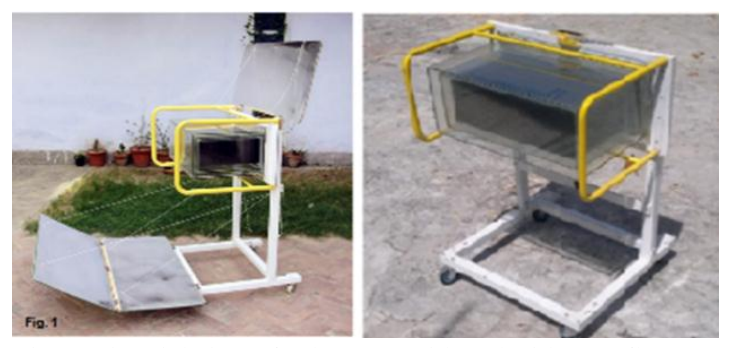

Fig. 1. Pictorial view of solar oven with and without reflectors.

\section{EXPERIMENTATION}

Experiments were conducted on the solar oven with and without reflectors, to record the maximum temperatures attained inside the solar oven during various times. Different foods were also cooked e.g., boiled potatoes, boiled rice, boiled eggs and noodles. The experimental tests were carried out on different days during the month of March and April 2014.

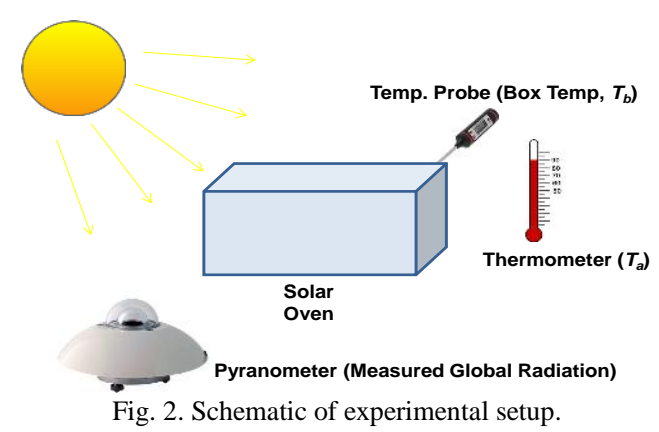

Schematic of the experimental setup is shown in Fig. 2. During experiments, solar oven was placed in a position so that the projection of sun rays on the ground and surface normal of the front face of oven coincides i.e., solar surface azimuth angle always approaches to zero. Oven was placed in the sun for several hours i.e., for a time period long enough to ensure steady state conditions to prevail. Temperature inside the box cavity was then recorded through a temperature probe (UT33B, Uni-Trend) inserted inside cavity. Available global 
solar radiation was also recorded using a pyranometer. The pyranometer was made available by IESE NUST. On a clear sky day, typical box temperatures attained were in the range of 140 and $100{ }^{\circ} \mathrm{C}$ with and without reflectors, respectively. The temperatures achieved are well above the required safe cooking temperatures for most of the foods (i.e, 60-90 ${ }^{\circ} \mathrm{C}$ ). Tables I and II list some of the results of measured data without and with reflectors, respectively.

TABLE I: EXPERIMENTAL BOX TEMPERATURE WHILE USING THE SOLAR

\begin{tabular}{ccccc}
\multicolumn{5}{c}{ OvEN withOUT REFLECTORS } \\
\hline Day & $\begin{array}{c}\text { Time } \\
(\mathrm{hrs})\end{array}$ & $\begin{array}{c}\text { Solar } \\
\text { Radiation } \\
\left(\mathrm{W} / \mathrm{m}^{2}\right)\end{array}$ & $\begin{array}{c}\text { Ambient } \\
\text { Temperature } \\
\left({ }^{\circ} \mathrm{C}\right)\end{array}$ & $\begin{array}{c}\text { Temperature } \\
\text { of Box }\left({ }^{\circ} \mathrm{C}\right)\end{array}$ \\
\hline \multirow{2}{*}{ March } & 1030 & 367.9 & 20 & 25 \\
$16^{\text {th }}$ & 1300 & 460 & 22 & 72 \\
& & 537 & 22 & 60 \\
March & 1300 & 812.8 & 25 & 93 \\
$20^{\text {th }}$ & 1400 & 719.62 & 24 & 105 \\
& 1500 & 643.14 & 24 & 92 \\
\hline
\end{tabular}

TABLE II: EXPERIMENTAL BOX TEMPERATURE WHILE USING THE SOLAR

\begin{tabular}{|c|c|c|c|}
\hline \multicolumn{4}{|c|}{ OVEN WITH REFLECTORS } \\
\hline Day & $\begin{array}{l}\text { Time } \\
\text { (hrs) }\end{array}$ & $\begin{array}{c}\text { Ambient Temperature } \\
\left({ }^{\circ} \mathrm{C}\right)\end{array}$ & $\begin{array}{l}\text { Temperature of Box } \\
\left({ }^{\circ} \mathrm{C}\right)\end{array}$ \\
\hline \multirow{4}{*}{ April $6^{\text {th }}$} & 1000 & 22 & 90 \\
\hline & 1100 & 23 & 99 \\
\hline & 1200 & 23 & 124 \\
\hline & 1300 & 22 & 113 \\
\hline \multirow{4}{*}{ April $20^{\text {th }}$} & 1000 & 22 & 28 \\
\hline & 1100 & 23 & 87 \\
\hline & 1200 & 23 & 145 \\
\hline & 1300 & 23 & 132 \\
\hline \multirow{4}{*}{ April $25^{\text {th }}$} & 0900 & 22 & 30 \\
\hline & 1000 & 23 & 81 \\
\hline & 1100 & 23 & 104 \\
\hline & 1200 & 24 & 164 \\
\hline
\end{tabular}

*Solar radiation data was not available for April 2014.

\section{MATHEMATICAL MODELING}

A simplified steady state numerical model based on 1D heat transfer of the oven without reflectors is formulated. Under steady state condition overall energy balance of the solar oven (see Fig. 3) is expressed as:

$$
S=I(\tau \alpha)=U\left(T_{b}-T_{a}\right)
$$

where $S$ is the total amount of radiation which is absorbed on the surface of the inner box. Absorbed solar radiations are calculated for front, top and side faces separately and added to get the total radiation that is absorbed by the black box. i.e.; amount of heat absorbed $Q_{a b}$ is given as:

$$
Q_{a b}=S_{t} A_{t}+S_{f} A_{f}+2\left(S_{s} A_{s}\right)
$$

where $S_{t}, S_{f}$ and $S_{s}$ are the absorbed radiation on top, front and two sides of the inner oven box, respectively. $A_{t}, A_{f}$ and $A_{s}$ are the corresponding areas of the inner oven box.

The radiations absorbed by these four faces are calculated separately using the isotropic diffuse model for hourly absorbed radiation [12].

$$
\begin{aligned}
S= & I_{b} R_{b}(\tau \alpha)_{b}+I_{d}(\tau \alpha)_{d}\left(\frac{1+\cos \beta}{2}\right)+ \\
& \left(I_{d}+I_{b}\right)(\tau \alpha)_{g}\left(\frac{1-\cos \beta}{2}\right) \rho_{g}
\end{aligned}
$$

The model caters for beam, diffused and ground reflected components of incident radiation on absorbing sides of oven as mentioned by subscripts $b, d$ and $g$ in (3). It is to be noted that the radiation absorbed by the two sides (z-direction in Fig. 3) consists of only ground reflected radiation.

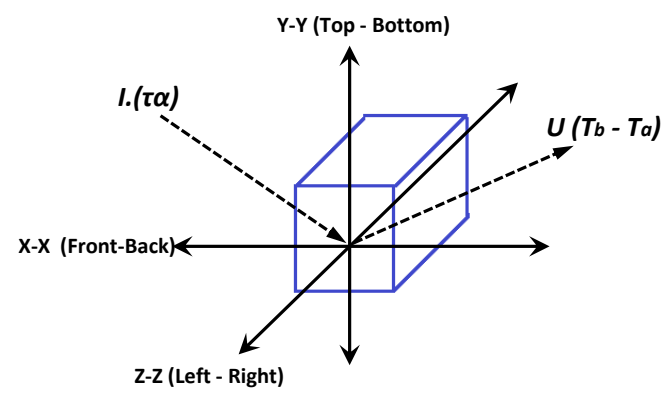

Fig. 3. Overall energy balance of solar oven.

$U\left(T_{b}-T_{a}\right)$ is the heat loss per unit area of the solar oven from oven box to ambient. For estimating overall heat loss coefficient $(U)$ six individual thermal resistance networks with a common box temperature $\left(T_{b}\right)$ is established to represent all the relevant heat loss coefficients involved from oven box to common ambient $\left(T_{a}\right)$ from all six sides.

The model caters for beam, diffused and ground reflected components of incident radiation on absorbing sides of oven as mentioned by subscripts $b, d$ and $g$ in (3). It is to be noted that the radiation absorbed by the two sides (z-direction in Fig. 3) consists of only ground reflected radiation.

$U\left(T_{b}-T_{a}\right)$ is the heat loss per unit area of the solar oven from oven box to ambient. For estimating overall heat loss coefficient $(U)$ six individual thermal resistance networks with a common box temperature $\left(T_{b}\right)$ is established to represent all the relevant heat loss coefficients involved from oven box to common ambient $\left(T_{a}\right)$ from all six sides (see Fig. 4).

Heat loss coefficients from box to ambient from top, front, sides, bottom and back of solar oven are expressed as follows:

$$
\begin{gathered}
U_{\text {top }}=\left[\frac{1}{h_{c-t-b g 1}+h_{r-t-b g 1}}+\frac{1}{h_{c-t-g 1 g 2}+h_{r-t-g 1 g 2}}+\frac{1}{h_{c-t-g 2 a}+h_{r-t-g 2 a}}\right]^{-1} \\
U_{\text {front }}=\left[\frac{1}{h_{c-f-b g 1}+h_{r-f-b g 1}}+\frac{1}{h_{c-f-g 1 g 2}+h_{r-f-g 1 g 2}}+\frac{1}{h_{c-f-g 2 a}+h_{r-f-g 2 a}}\right]^{-1} \\
U_{\text {right }, \text { left }}=\left[\frac{1}{h_{c-r, l-b g 1}+h_{r-r, l-b g 1}}+\frac{1}{h_{c-r, l-g 1 g 2}+h_{r-r, l-g 1 g 2}}+\frac{1}{h_{c-r, l-g 2 a}+h_{r-r, l-g 2 a}}\right]^{-1}
\end{gathered}
$$




$$
\begin{gathered}
U_{b}=\left[\frac{1}{h_{r-b-b g 1+}{ }^{k_{b-b g 1} / L}}+\frac{1}{h_{r-b-g 1 g 2}{ }^{k_{b-g 1 g 2} / L}}+\frac{1}{h_{c-b-g 2 a}+h_{r-b-g 2 a}}\right] \\
U_{b a c k}=\frac{k}{L_{b}}
\end{gathered}
$$

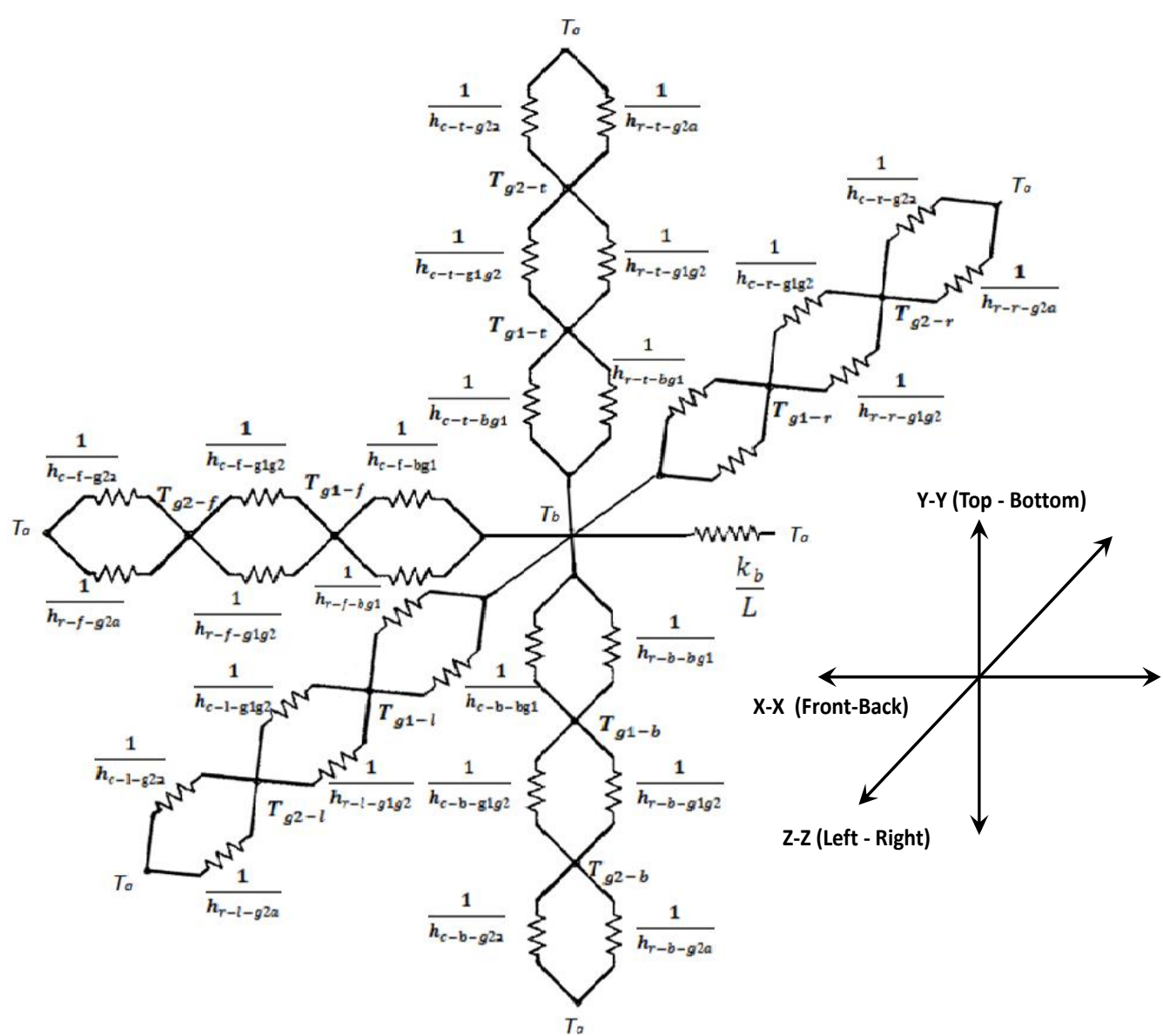

Fig. 4. Integrated thermal resistance network.

Overall Heat loss coefficient is then given as:

$U_{\text {total }}=U_{\text {top }}+U_{b}+U_{\text {left }}+U_{\text {front }}+U_{\text {right }}+U_{\text {back }}$

Appropriate correlations for finding the radiative and convective (free and wind) heat transfer coefficients are used in (4-7) to find the overall heat transfer coefficients [12], [13] Box and glass temperatures $\left(T_{b}, T_{c 1}, T_{c 2}\right)$ are required to calculate the radiative and conductive heat transfer coefficients. Unknown box temperature $(\mathrm{Tb})$ can be calculated iteratively using (1) and (2) and is expressed as:

$$
T_{b}=T_{a}+\frac{S_{t} \cdot A_{b t}+S_{f} \cdot A_{b f}+2\left(S_{s} \cdot A_{b s}\right)}{U_{\text {total }}\left(A_{\text {loss }}\right)}
$$

Unknown glass cover temperatures are also calculated iteratively using the following equations [12]:

Temperature of cover 1 for any face of solar oven is given by:

$$
T_{c 1}=T_{b}-\frac{U_{t o t a l}\left(T_{b}-T_{a}\right)}{h_{c-b g 1}+h_{r-b g 1}}
$$

Temperature of cover 2 for any face of solar oven is given by:

$$
T_{c 2}=T_{c 1}-\frac{U_{t o t a l}\left(T_{b}-T_{a}\right)}{h_{c-g 1 g 2}+h_{r-g 1 g 2}}
$$

Mathematical model is implemented in a computer program to perform iterative calculations until the convergence of unknown box and glass cover temperatures.

\section{MODEL VALIDATION}

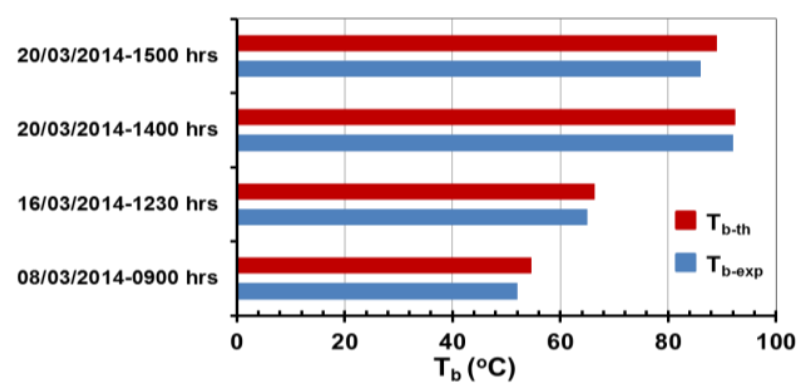

Fig. 5. Experimental and mathematical $T_{b}\left({ }^{\circ} \mathrm{C}\right)$.

Validation of the mathematical model is checked by comparing results with the experimentally obtained data. Fig. 5 shows the comparison of numerically and experimentally obtained box temperatures $\left(T_{b}\right)$ for different values of available radiations and found to be in close agreement to 
each other. Owing to various simplified assumptions, theoretical temperatures $\left(T_{b-t h}\right)$ are always a bit higher then experimental temperatures $\left(T_{b-e x p}\right)$ but both are in proximity of about $0.5-4 \%$ which validates the model.

\section{RESUlTS AND PARAMETRIC ANALYSIS}

Parametric analysis of the solar oven was done to study the effects of various parameters on its thermal performance. The results along with the parameters that were analyzed are discussed below.

Number of Glazing. Effect of number of glazings on oven's thermal performance is investigated numerically and the results for single and double glazing are listed in Table III.

From Table III, it can be seen that the absorbed solar radiation increase for the single glazed solar oven compared with the solar oven with double glazing. But because of the lower heat loss coefficient of the double glazed oven than the single glazed one, it results in higher box temperature $\left(T_{b}\right)$. This implies that the effect of $U\left(\mathrm{~W} / \mathrm{m}^{2} \mathrm{~K}\right)$ is more dominant as compared to optical losses $(\tau \alpha)$. The single glazed thus absorbs more heat and losses more heat as well which resulted in lower $T_{b}$ then for doubled glazed oven.

\section{A. Effects of Surface Coating}

Solar oven's performance using different types of surface coatings for the cooking cavity was examined. Different types of surface coatings were selected for the analysis. Table IV lists the results. It can be seen that Tinox and black crystal coatings, due to their low thermal emittance, result in an increased $T_{b}$ up to $40{ }^{\circ} \mathrm{C}$ when compared to black paint.

TABLE III: COMPARISON OF MEASURED AND ABSORBED SOLAR INSOLATION, TRANSMITTANCE-ABSORPTANCE PRODUCT FROM BEAM RADIATION, OVERALl HEAT LOSS COEFFICIENT AND BOX TEMPERATURE FOR SINGLE AND DOUBLE GLAZING

\begin{tabular}{|c|c|c|c|c|c|c|c|c|c|c|c|c|}
\hline \multirow[t]{2}{*}{$\begin{array}{c}\text { Available } \\
\text { Solar } \\
\text { Insolation } \\
{\left[\mathrm{W} / \mathrm{m}^{2}\right]}\end{array}$} & \multicolumn{2}{|c|}{$\begin{array}{c}\text { Absorbed Solar } \\
\text { Insolation Top } \\
{\left[\mathrm{MJ} / \mathrm{m}^{2}\right]}\end{array}$} & \multicolumn{2}{|c|}{$\begin{array}{c}\text { Absorbed Solar } \\
\text { Insolation Front } \\
{\left[\mathrm{MJ} / \mathrm{m}^{2}\right]}\end{array}$} & \multicolumn{2}{|c|}{$\tau \alpha_{\mathrm{b} \text { Top }}$} & \multicolumn{2}{|c|}{$\tau \alpha_{b}$ Front } & \multicolumn{2}{|c|}{$\begin{array}{l}\text { Overall Heat Transfer Loss } \\
\text { Coefficient } U\left[\mathrm{~W} / \mathrm{m}^{2} \mathrm{C}\right]\end{array}$} & \multicolumn{2}{|c|}{$\begin{array}{c}\text { Box Temperature } \\
{\left[{ }^{\circ} \mathrm{C}\right]}\end{array}$} \\
\hline & $\begin{array}{l}\text { Single } \\
\text { Glazing }\end{array}$ & $\begin{array}{l}\text { Double } \\
\text { Glazing }\end{array}$ & $\begin{array}{l}\text { Single } \\
\text { Glazing }\end{array}$ & $\begin{array}{l}\text { Double } \\
\text { Glazing }\end{array}$ & $\begin{array}{l}\text { Single } \\
\text { Glazing }\end{array}$ & $\begin{array}{l}\text { Double } \\
\text { Glazing }\end{array}$ & $\begin{array}{l}\text { Single } \\
\text { Glazing }\end{array}$ & $\begin{array}{l}\text { Double } \\
\text { Glazing }\end{array}$ & $\begin{array}{l}\text { Single } \\
\text { Glazing }\end{array}$ & $\begin{array}{l}\text { Double } \\
\text { Glazing }\end{array}$ & $\begin{array}{l}\text { Single } \\
\text { Glazing }\end{array}$ & $\begin{array}{l}\text { Double } \\
\text { Glazing }\end{array}$ \\
\hline 322.2 & 0.94 & 0.77 & 0.93 & 0.79 & 0.76 & 0.63 & 0.8315 & 0.75 & 5.21 & 3.48 & 40.8 & 45.1 \\
\hline 537.2 & 1.51 & 1.26 & 1.27 & 0.93 & 0.82 & 0.72 & 0.79 & 0.67 & 5.66 & 3.83 & 56.3 & 62.9 \\
\hline 812.8 & 2.08 & 1.78 & 2.15 & 1.83 & 0.816 & 0.70 & 0.819 & 0.70 & 6.08 & 4.18 & 73.1 & 82.5 \\
\hline 643.1 & 1.8 & 1.50 & 2.65 & 2.33 & 0.78 & 0.65 & 0.82 & 0.72 & 6.09 & 4.17 & 73.3 & 81.7 \\
\hline
\end{tabular}

\begin{tabular}{|c|c|c|c|c|}
\hline Coating & Absorptance & Emittance & $\begin{array}{c}\text { Loss Coefficient } \\
\left.\left[\mathrm{W} / \mathrm{m}^{2} \mathrm{C}\right)\right]\end{array}$ & $\begin{array}{c}\text { Temperature of Box } \\
{\left[{ }^{\circ} \mathrm{C}\right]}\end{array}$ \\
\hline Black Paint & 0.98 & 0.98 & 4.18 & 82.5 \\
\hline Solec SOLKOTE selective surface paint & $0.88-0.94$ & $0.28-0.49$ & 2.86 & 108.54 \\
\hline Black Crystal & $0.92-0.98$ & $0.08-0.25$ & 2.5 & 120.5 \\
\hline Copper treated with $\mathrm{NaClO}_{2}$ and $\mathrm{NaOH}$ & 0.87 & 0.13 & 2.7 & 108.15 \\
\hline Solchrome & $0.94-0.98$ & $0.10-0.14$ & 2.69 & 115.7 \\
\hline Metal, plated Black sulphide & 0.92 & 0.10 & 2.69 & 115.7 \\
\hline Metal, plated Black chrome & 0.87 & 0.09 & 2.63 & 112.85 \\
\hline Metal, plated Nickel oxide & 0.92 & 0.08 & 2.61 & 118.5 \\
\hline Metal, plated Cobalt oxide & 0.93 & 0.30 & 3.26 & 98.16 \\
\hline Tinox & 0.98 & 0.08 & 2.43 & 124.22 \\
\hline
\end{tabular}

\section{B. Effect of Plate Spacing}

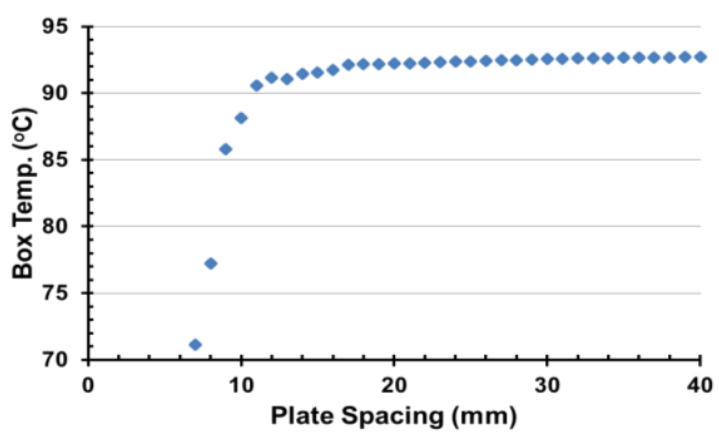

Fig. 6. Graph between box temperature $\left(T_{b}\right)$ and plates spacing.

In our solar oven the air gap between the first and second glass cover and the air gap between the first glass cover and the metal box is $25 \mathrm{~mm}$. The effect of spacing between oven box and inner glazing and between inner and outer glazing is studied. Fig. 6 illustrates the effect of spacing between oven box and inner glazing and between the glazings. It can be seen that by decreasing the plate spacing $T_{b}$ decreases but till $20 \mathrm{~mm}$ the drop is marginal. $T_{b}$ decreases then significantly as spacing is reduced from $20 \mathrm{~mm}$ onwards.

\section{CONCLUSION}

The thermal performance of a 5-sided solar oven is investigated experimentally and numerically. Experimental analysis showed temperature attained within the oven box with and without reflectors was in the range of $50-150{ }^{\circ} \mathrm{C}$, which is adequate for cooking purposes. A mathematical model of the solar oven (without reflectors) based on steady state heat transfer and isotropic diffuse sky model is developed and implemented in a computer program to solve 
it iteratively. Mathematical and experimental results are found to be in good agreement. Parametric study is then conducted to analyze the effect of various key parameters. Double glazing results in better thermal performance than single glazing. Using a selective coating (i.e. TiNox) on the outer surface of the oven box temperature $T_{b}$ can be increased up to $50^{\circ} \mathrm{C}$, when compared to black paint. Below $20 \mathrm{~mm}$ of spacing between oven box and glazings results in significant drop of box temperature $T_{b}$. Plate spacing of $25 \mathrm{~mm}$ and above does not improve the oven thermal performance appreciably.

Mathematical model can be extended further to incorporate the effects of reflectors (i.e., flat and/or parabolic). Transient analysis of the oven will be useful to reduce the time to attain desired cooking temperatures. Options of creating and maintaining vacuum between the oven cavity and glass can be explored to enhance the thermal performance of the oven during periods of low insolation.

\section{NOMENCLATURE}

$A_{b f} \quad$ Area of front surface of box $\left[\mathrm{m}^{2}\right]$

$A_{\text {loss }} \quad$ Total area of heat loss $\left[\mathrm{m}^{2}\right]$

$h_{c} \quad$ Convection heat transfer coefficient $\left[\mathrm{W} / \mathrm{m}^{2} \mathrm{~K}\right]$

$h_{r} \quad$ Radiation heat transfer coefficient $\left[\mathrm{W} / \mathrm{m}^{2} \mathrm{~K}\right]$

Subscripts of $h_{r}$ and $h_{c}$ :

$t$-bg1: box to 1 st cover at top surface, $f$-bg 1 : box to 1 st cover at front surface

$r$-bg 1: box to 1 st cover at right surface, $l-b g 1$ : box to 1 st cover at left surface

$b-b g 1$ : box to 1 st cover at bottom surface, $t$-g $\lg 2$ : 1 st cover to 2 nd cover at top surface

$f$-glg2: 1 st cover to 2 nd cover at front surface, $r-g 1 g 2: 1$ st cover to 2nd cover at right surface

l-glg2: 1st cover to 2 nd cover at left surface, and so on.

\begin{tabular}{|c|c|}
\hline$h_{w}$ & Convection heat transfer coefficient of air $\left[\mathrm{W} / \mathrm{m}^{2} \mathrm{~K}\right]$ \\
\hline$I_{b, d, r}$ & $\begin{array}{l}\text { Beam, diffused or ground reflected solar radiation } \\
{\left[\mathrm{W} / \mathrm{m}^{2}\right]}\end{array}$ \\
\hline$k_{1}$ & $\begin{array}{l}\text { Thermal conductivity of air between box and } 1 \text { st cover } \\
\text { at bottom surface }[\mathrm{W} / \mathrm{m} \mathrm{K}]\end{array}$ \\
\hline$k_{2}$ & $\begin{array}{l}\text { Thermal conductivity of air between } 1 \text { st cover and } 2 \text { nd } \\
\text { cover at bottom surface }\left[\mathrm{W} / \mathrm{m}^{2} \mathrm{~K}\right]\end{array}$ \\
\hline$k_{b}$ & Thermal conductivity of back material $\left[\mathrm{W} / \mathrm{m}^{2} \mathrm{~K}\right]$ \\
\hline$L$ & Surface spacing $[\mathrm{m}]$ \\
\hline$L_{b}$ & Thickness of back material [m] \\
\hline$Q_{\text {in }}$ & Total energy going inside box [Watts] \\
\hline$Q_{\text {out }}$ & Total energy loss from box [Watts] \\
\hline$S_{t}$ & Radiation absorbed by top surface $\left[\mathrm{W} / \mathrm{m}^{2}\right]$ \\
\hline$S_{f}$ & Radiation absorbed by front surface $\left[\mathrm{W} / \mathrm{m}^{2}\right]$ \\
\hline$T_{b}$ & Temperature of box $\left[{ }^{\circ} \mathrm{C}\right.$ or $\left.\mathrm{K}\right]$ \\
\hline$T_{c 1, c 2}$ & Temperature of glass cover 1 and $2\left[{ }^{\circ} \mathrm{C}\right.$ or $\left.\mathrm{K}\right]$ \\
\hline$T_{a}$ & Ambient temperature $\left[{ }^{\circ} \mathrm{C}\right.$ or $\left.\mathrm{K}\right]$ \\
\hline$\dot{U}$ & Overall heat loss coefficient at top surface $\left[\mathrm{W} / \mathrm{m}^{2} \mathrm{~K}\right]$ \\
\hline$(\tau \alpha)_{b, d, g}$ & $\begin{array}{l}\text { Transmittance-absorbtance product for beam, diffused } \\
\text { or reflected Radiation [-] }\end{array}$ \\
\hline$\beta$ & Slope [degrees] \\
\hline$\rho_{g}$ & Ground reflectance $[-]$ \\
\hline
\end{tabular}

\section{REFERENCES}

[1] N. M. Nahar, "Performance and testing of an improved hot box solar cooker," Energy Conversion and Management, vol. 30, pp. 9-16, 1990.

[2] R. S. Mishra and S. P. Prakash, "Evaluation of solar cooker thermal performance using different insulating materials," International Journal of Energy Research, vol. 8, pp. 393-396, 1984.
[3] N. M. Nahar, "Studies on a hot box solar cooker with transparent insulation material," Energy Conversion and Management, vol. 9, pp. 787-791, 1994.

[4] A. H. Algifri and H. A. Al-Towaie, "Efficient orientation impacts of box-type solar cooker on the cooker performance," Solar Energy, vol. 70, pp. 165-170, 2001

[5] S. Kumar, "Estimation of design parameters for thermal performance evaluation of box-type solar cooker," Renewable Energy, vol. 30, pp. 1117-1126, 2005.

[6] S. M. A. Ibrahim and M. K. El-Reidy, "The performance of a solar cooker in Egypt," Renewable Energy, vol. 8, pp. 1041-1050, 1995.

[7] H. P. Garg, B. Bandyopadhyay, and G. Datta, "Mathematical-modeling of the performance of a solar oven," Applied Energy, vol. 14, pp. 223-239, 1983.

[8] J. S. Vaishya, T. C. Tripathi, D. Singh, R. H. Bhawalkar, and M. S. Hegde, "A hot box solar cooker performance analysis and testing," Energy Conversion and Management, vol. 25, pp. 373-375, 1985.

[9] T. C. T. D. Skpr, "Solar box-cooker," Solar Energy, vol. 52, no. 3, pp. 265-272, 1994.

[10] A. K. Bidotnark and N. Türkmen, "Modelling of a hot box solar cooker," Energy Conversion and Management, vol. 37, pp. 303-310, 1996.

[11] Y. P. Yadav and G. N. Tiwari, "Transient analytical study of box-type solar cooker," Energy Conversion and Management, vol. 27, no. 2, pp. 121-127, 1987.

[12] J. A. Duffie and W. A. Beckman, Solar Engineering and Thermal Processes, 4th Ed. New Jersey: John Wiley \& Sons, 2013, ch. 4-6.

[13] Y. A. Cengel, Heat Transfer: A Practical Approach, 2nd Ed. McGraw-Hill, 2003, ch. 9-12.

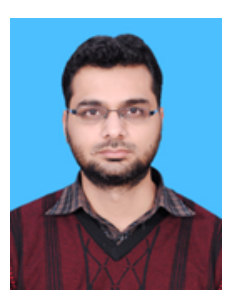

Abdul Waheed Badar was born in Sahiwal, Pakistan on July 21,1982 . He received the bachelor's degree in mechanical engineering from University of Engineering and Technology, Taxila in 2004 and the master's degree in mechanical engineering from the same university in 2006. He did his $\mathrm{PhD}$ program from Technical University of Berlin in 2012. His major fields of study are solar thermal collectors, solar heating and cooling, and heat transfer.

$\mathrm{He}$ has been working as an assistant professor in the Mechanical Engineering Department, National University of Sciences and Technology, since 2013 .

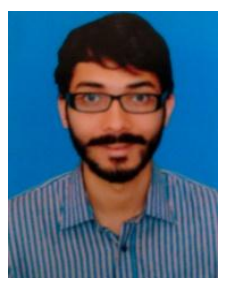

Syed Ali Zaryab was born in Lahore, Punjab, Pakistan, in July 1991. He completed his bachelor degree in mechanical engineering from National University of Science and Technology, Punjab, Pakistan, in 2014. His area of interest is renewable energy technologies.

He is currently working in the Business Technology Service Department of HBL, Sindh, Pakistan.

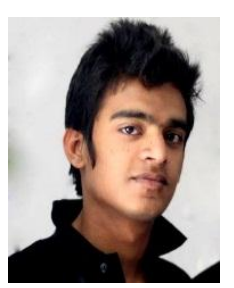

Zain Ul Abedin was born in Faisalabad, Pakistan. He is right now working in a major FMCG multinational organization. Previously he's also been working in design and optimization engineering fields. He has earned his degree in mechanical engineering from National University of Sciences and Technology (NUST) Islamabad in 2014

He's been one of the semifinalists in Cleantech Global 2014, an entrepreneurship competition organized by UNIDO and runners up at Preston Entrepreneurial Challenge ' 14 , pitching his sustainable green energy business ideas in both competitions. His areas of interest are using renewable energy sources at micro level and utilizing them in the form of simple consumer products.

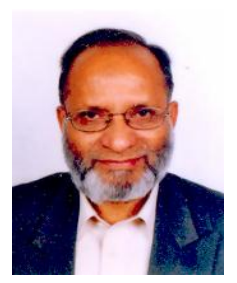

Muhammad Yasin Khan was born in Chichawatni District Sahiwal, Punjab, Pakistan in April 1943. He did his F.Sc degree in 1962 from Islamia College Faisalabad, Punjab, Pakistan. His areas of interest are renewable energy and environmental science. He is an inventor and holds the intellectual property rights of five out of nine of his inventions related to clean and green technology for sustainable living. He is the CEO of a private business, "REPRO" Renewable Energy Promoters at Chichawatni, Pakistan. 